\title{
Juvenile Lupus Erythematosus: Fourteen Years of Experience
}

\author{
Juvenil Lupus Eritematozus: On Dört Yıllık Deneyim
}

Funda BAŞTUĞ, Hakan POYRAZOĞLU, Zübeyde GÜNDÜZ, Sebahat TÜLPAR, Ruhan DÜŞÜNSEL

Department of Pediatrics Nephrology and Rheumatology, Medical Faculty of Erciyes University, Kayseri, Turkey

Objectives: This study aims to describe the main clinical and laboratory features as well as the morbidity and mortality of juvenile systemic lupus erythematosus (JSLE) in Turkish children.

Patients and methods: Thirty children (27 girls, 3 boys; mean age at diagnosis 12.3 years; range 3 to 16 years) with JSLE were evaluated retrospectively. All patients met the 1982 American College of Rheumatology revised criteria for the diagnosis of SLE and had shown clinical manifestations of the disease before the age of 16 .

Results: The mean period of follow-up was 2.9 years (range 2 months-10 years) and the mean duration of symptoms before diagnosis was 3.3 months (range 2 days-2 years). The frequencies of the clinical and laboratory features of the patients were as follows: erythematous malar rash was seen in 17 (56\%), discoid rash in one, photosensitivity in 16 (53.3\%), oral ulcers in eight (26.7\%), musculoskeletal involvement in $26(87 \%)$, serositis in $13(43 \%)$, hematological abnormalities in $21(70 \%)$, renal involvement in 17 (56\%), antinuclearantibody positivity in 27 (93\%), pulmonary involvement in eight $(27 \%)$, cardiovascular disease in seven (23\%), and central nervous system involvement in seven patients (23\%). During the follow-up four patients (13\%) died, three of renal failure and one from sepsis. During the study two patients were in remission without treatment and 22 patients were in remission with treatment. Two patients were lost to follow-up.

Conclusion: Juvenile systemic lupus erythemathosus is a serious multisystem organ disease. Although JSLE has a high remission rate with early diagnosis and treatment, it still has a significant mortality rate.

Key words: Juvenile; lupus nephritis; outcome; systemic lupus erythematosus; treatment.
Amaç: Bu çalışmada Türk çocuklarda juvenil sistemik lupus eritematozusa (JSLE) ilişkin temel klinik ve laboratuvar özellikler ve yanı sıra morbidite ve mortalitenin tanımlanması amaçlandı.

Hastalar ve yöntemler: Otuz JSLE'li çocuk (27 kız, 3 erkek; ort. tanı yaşı 12.3 yıl; dağılım 3-16 yıl) retrospektif olarak değerlendirildi. Hastaların hepsi SLE tanısına ilişkin revize edilmiş 1982 Amerikan Romatoloji Birliği kriterlerini karşılamaktaydı ve 16 yaşından önce hastalığın klinik bulgularını sergilemişti.

Bulgular: Ortalama takip süresi 2.9 yıl (dağılım 2 ay-10 yıl), tanı öncesi semptomların ortalama süresi ise 3.3 ay (dağılım 2 gün-2 yıl) idi. Hastaların klinik ve laboratuvar özelliklerinin sıklığı şöyle idi: eritematöz malar döküntü 17 (\%56), discoid döküntü bir (\%3.3), fotosensitivite 16 (\%53.3), oral ülser sekiz (\%26.7), kas-iskelet tutulumu 26 (\%87), serözit 13 (\%43), hematolojik anormallikler $21(\% 70)$, renal tutulum 17 (\%56), antinükleer antikor pozitifliği 27 (\%93), pulmoner tutulum sekiz (\%27), kardiyovasküler hastalık yedi (\%23) ve merkezi sinir sistemi tutulumu yedi (\%23) hastada görüldü. İzlem sırasında üçü böbrek yetmezliğinden, biri sepsisten olmak üzere dört hasta öldü (\%13). Çalışma sırasında iki hasta tedavisiz remisyonda, 22 hasta ise tedavi ile remisyonda takip edilmekte idi. İki hasta ise takipten çıkmış idi.

Sonuç: Juvenil sistemik lupus eritematozus ciddi, multisistemik bir organ hastalığıdır. JSLE erken tanı ve tedavi ile yüksek bir remisyon oranı sergilemesine karşın, hala önemli bir mortalite oranına sahiptir.

Anahtar sözcükler: Juvenil; lupus nefriti; sonuç; sistemik lupus eritematosus; tedavi.

\footnotetext{
Received: September 20, 2010 Accepted: June 6, 2011

Correspondence: Funda Baştuğ, M.D. Erciyes Üniversitesi Tıp Fakültesi Pediatri Nefroloji ve Romatoloji Bilim Dalı, 38039 Talas, Kayseri, Turkey. Tel: +90 352 - 2378239 e-mail: fundadr@hotmail.com 
Systemic lupus erythematosus (SLE) is a chronic autoimmune disease with a wide spectrum of clinical and immunological abnormalities. ${ }^{[1]}$ Although SLE is most commonly found in women of childbearing age, lupus is not confined to adulthood, and nearly $10-15 \%$ of cases present in children younger than 16 years. ${ }^{[2,3]}$ Juvenile systemic lupus erythematosus (JSLE) is rarely seen in children under five years of age, and the peak incidence of childhood SLE occurs around puberty. ${ }^{[4]}$ The clinical manifestations of the disease, which are remarkably diverse, include fever, erythematous rash, polyarthralgia and arthritis, polyserositis, anemia, and thrombocytopenia along with renal, neurological and cardiac abnormalities, such as pericarditis, myocarditis and endocarditis. ${ }^{[5]}$ Rates of organ involvement are higher in children compared with adult lupus patients. This observation may be expected as pediatric patients tend to have more severe symptoms at onset. ${ }^{[6,7]}$ Many investigators have described the features of JSLE among different geographical groups. ${ }^{[8-14]}$

This is the first retrospective study which takes into account all clinical, laboratory, and pathological features of Turkish children with JSLE who were treated at our center over the last 14 years.

\section{PATIENTS AND METHODS}

The medical records of 30 children ( 27 girls, 3 boys; mean age 12.3 years; range 3 to 16 years) with SLE treated between July 1995 and May 2009 at the Department of Pediatric Nephrology, Erciyes University Medical Faculty, Kayseri, Turkey, were retrospectively analyzed. All patients fulfilled the American College of Rheumatology 1982 revised criteria for the diagnosis of SLE ${ }^{[15]}$ and had shown clinical manifestations of the disease before the age of 16 .

Data on clinical manifestations and laboratory findings, gender, date of birth, and age at diagnosis were obtained by reviewing medical records. Detailed information of clinical disease expression was reviewed, including involvement of skin, musculoskeletal, renal, pulmonary, cardiovascular, central nervous system, and hematologic abnormalities. Renal biopsies were done in all patients with clinical evidence of lupus nephritis (LN). The evidence of $\mathrm{LN}$ included hypertension, abnormal urinalysis, and/or elevated serum creatinine concentrations. Hypertension was defined as systolic and/or diastolic blood pressure above the $95^{\text {th }}$ percentile for gender and age. Abnormal urinalysis was considered when there were $\geq 5$ red blood cells or white blood cells per high-power field, urine protein $\geq 1 \mathrm{~g} / \mathrm{l}$, and/or casts. Nephrotic proteinuria was defined as protein $>1 \mathrm{~g} / \mathrm{m}^{2}$ in a 24 -hour urine collection. ${ }^{[20]}$ Serum creatinine $>1 \mathrm{mg} / \mathrm{dl}$ was considered abnormal. ${ }^{[14]}$

A biopsy was usually performed within one to two months of clinical diagnosis. Specimens were processed for light and fluorescent microscopy. Renal lesions were classified according to the World Health Organization (WHO) classification criteria for LN. ${ }^{[16]}$

Laboratory investigations included a complete blood count (CBC), erythrocyte sedimentation rate (ESR), $\mathrm{C}$-reactive protein (CRP), kidney function tests (serum creatinine and blood urea nitrogen), Coombs' test, antinuclear antibodies (ANA), anti-double-stranded DNA (anti-dsDNA), anti-Smith antibody (antiSm), anti-phospholipid antibodies, and complement fractions (C3 and C4).

The duration of follow-up was calculated from the time of SLE diagnosis until the patient's last clinic visit. The outcome was classified as follows: (i) remission, (ii) active disease, (iii) death, and (iv) lost to follow-up. Remission was defined as patients having normal urine analysis, blood pressure, and serum creatinine with no evidence of active extrarenal manifestations. Active disease was diagnosed in the presence of active urine sediment, proteinuria, and/or hypertension or active extrarenal manifestations. ${ }^{[14]}$ The patients with partial remission were categorized in the active disease group. Patients who did not show up in the clinic while they still had active disease and those for whom we had no further information about the course of their disease were labeled as lost to follow-up.

\section{Statistical analysis}

All the analyses were performed using Statistical Package for Social Sciences (SPSS Inc., Chicago, Illinois, USA) for Windows 17.0. The data used was proven to be normally distributed by passing the Shapiro-Wilk normality test. The parameters with normal distribution were expressed as mean \pm standard deviation $( \pm S D)$, and the parameters with abnormal distribution were expressed as median (minimum-maximum). A descriptive analysis was performed to analyze the frequency of the clinical manifestations, immunological findings, and requirement of pharmacologic treatment during the course of disease by percentage. Spearman correlation analysis was performed to determine the relationship between C-reactive protein (CRP) and erythrocyte sedimentation rate (ESR). 


\section{RESULTS}

The mean age at disease onset, defined as the time of appearance of the first symptoms attributed to JSLE, was 11.9 \pm 3.4 years (range 2.9-16 years). A few patients had a delay in diagnosis that amounted to one and a half years, but the majority of our study group was diagnosed within a few months of presentation. The mean duration of symptoms before diagnosis was $3.3 \pm 1$ months (range 2 days -2 years). The average age at diagnosis was $12.3 \pm 3.2$ years (range 3-16 years). The disease was diagnosed before the age of 10 years in $20 \%$ of the patients and before the age of five years in one. The mean period of follow-up was 2.9 years (range 2 months-10 years). The clinical characteristics of children with systemic lupus erythematosus at presentation are listed in Table 1.

Table 1. Clinicopathologic features of systemic lupus erythematosus in Turkish children

\begin{tabular}{lcc}
\hline Manifestations & $\mathrm{n}$ & $\%$ \\
\hline Musculoskeletal & 26 & 87 \\
Arthralgia & 24 & 80 \\
Non-erosive arthritis & 23 & 77 \\
Myalgia & 8 & 27 \\
Constitutional symptoms & 24 & 80 \\
Fatigue & 11 & 36 \\
Weight loss & 7 & 23 \\
Anorexia & 13 & 43 \\
Vomiting & 5 & 17 \\
Fever & 17 & 56 \\
Mucocutaneous & 21 & 70 \\
Photosensitivity & 16 & 53 \\
Skin rash & 10 & 33 \\
Malar rash & 17 & 56 \\
Discoid rash & 1 & 3.3 \\
Oral ulceration & 8 & 27 \\
Raynaud's phenomenon & 5 & 17 \\
Serositis & 13 & 43 \\
Cardiac & 7 & 23 \\
Pericarditis & 1 & 3.3 \\
Pericardial effusion & 6 & 20 \\
Pulmonary & 8 & 27 \\
Pleural effusion & 7 & 23 \\
Pulmonary hypertension & 10 & 3.3 \\
Renal involvement & 17 & 56 \\
Central nervous system involvement & 7 & 23 \\
Seizures & 2 & 7 \\
Depression & 3 & 10 \\
Psychosis & 1 & 3.3 \\
Depression+seizures & 1 & 3.3 \\
Hematological & 21 & 70 \\
Anemia & 18 & 60 \\
Leukopenia & 53 \\
Thrombocytopenia & 33 \\
\hline
\end{tabular}

Musculoskeletal manifestations were the most common clinical features and were seen in $87 \%$ of our patients followed by constitutional symptoms $(80 \%)$. The least frequently involved organs were the pulmonary (27\%), cardiac (26\%), and central nervous system (CNS) (23\%). Among the CNS-involved patients, two had seizures, one had psychosis, three had depression, and one had seizures and depression.

Serositis was common (43\%) while pleural effusion was the most common pulmonary manifestation (27\%). It was associated with nephrotic syndrome in five cases. Pulmonary hypertension developed in one patient, and seven patients (23\%) exhibited cardiac involvement at some stage of their illness. Libman-Sacks endocarditis was not observed in any patients.

All the patients except two had a raised ESR at presentation with a mean value of $76 \pm 35.6$ in one hour. The CRP levels of 28 patients tested were low or moderately elevated. The mean value of CRP was $5.5 \pm 2.1 \mathrm{mg} / \mathrm{L}$. There was no correlation between the levels of CRP and ESR. The serological findings of patients with JSLE are shown in Table 2.

Renal disease was determined in $56 \%$ of the children in the study. Lupus nephritis was clinically evident at the time of JSLE diagnosis in 14 patients, and LN occurred in another four patients within one year of the diagnosis. Renal status and histopathological findings of renal biopsies are shown in Table 3. Proteinuria was

Table 2. Serological findings of children with systemic lupus erythematosus

\begin{tabular}{lcc}
\hline Laboratory features & $\mathrm{n}^{*} / \mathrm{n}^{* *}$ & $\begin{array}{c}\text { Frequencies } \\
(\%)\end{array}$ \\
\hline Antinuclear antibodies & $27 / 29$ & 93 \\
Anti-DNA antibodies & $12 / 28$ & 43 \\
Anti-dsDNA antibodies & $19 / 28$ & 68 \\
Anti-Sm antibodies & $5 / 28$ & 18 \\
Anti-SSA antibodies & $2 / 28$ & 7 \\
Anti-RNP antibodies & $5 / 28$ & 18 \\
Anti-histone antibodies & $6 / 28$ & 21 \\
Anti-nucleosome antibodies & $6 / 28$ & 21 \\
Rheumatoid factor & $7 / 29$ & 24 \\
Hypocomplementemia & $21 / 29$ & 70 \\
Low C3 & $18 / 29$ & 62 \\
Low C4 & $20 / 29$ & 69 \\
Direct Coombs & $19 / 29$ & 65 \\
Moderately elevated CRP levels & $13 / 28$ & 46 \\
Elevated ESR & $26 / 28$ & 93 \\
Anti-phospholipid antibodies & $7 / 28$ & 25 \\
\hline * Number of patients who tested positive; ** Number of patients that were tested; \\
DNA: Deoxiribo nucleic acid; Anti-dsDNA: Anti-double-stranded DNA; SSA: \\
Sjögren's Syndrome-A antibody; RNP: Ribonucleoprotein; CRP: C-reactive \\
protein; ESR: Erythrocyte sedimentation rate. \\
\hline
\end{tabular}




\begin{tabular}{|c|c|c|}
\hline \multirow[b]{2}{*}{ Feature } & \multicolumn{2}{|c|}{ Distribution of patients } \\
\hline & $\mathrm{n} / \mathrm{n}^{*}$ & $\%$ \\
\hline Hematuria & $12 / 17$ & 70 \\
\hline Microscopic & $9 / 17$ & 52 \\
\hline Macroscopic & $3 / 17$ & 17 \\
\hline Proteinuria & $13 / 17$ & 76 \\
\hline Non-nephrotic & $3 / 17$ & 17 \\
\hline Nephrotic & $10 / 17$ & 58 \\
\hline Elevated serum creatinine & $5 / 17$ & 29 \\
\hline Hypertension & $11 / 17$ & 64 \\
\hline \multicolumn{3}{|l|}{ Histopathologic findings } \\
\hline Class II & $6 / 17$ & 35 \\
\hline Class III & $1 / 17$ & 6 \\
\hline Class IV & $4 / 17$ & 23 \\
\hline Class V & $6 / 17$ & 35 \\
\hline
\end{tabular}

the most common urinary abnormality observed in LN patients (76\%), and it was in the nephrotic range of $58 \%$. Hematuria was evident in $70 \%$ of patients with $\mathrm{LN}$, and in most of them, it was microscopic. Sixteen patients with JSLE (53\%) had hypertension and 11 patients (64\%) with LN had hypertension while only five patients (29\%) had elevated serum creatinine. Sixteen out of 17 patients $(78 \%)$ with lupus nephritis who were tested had low fourth component of complement (C4) levels, and two out of $11(18 \%)$ patients that tested negative for nephritis also had a low level of serum C4.

Table 4 summarizes the main SLE treatments prescribed during follow-up. All our patients were treated with anti-inflammatory medications, and 17 patients received nonsteroidal anti-inflammatory drugs (NSAIDs). Of the 30 patients, 27 received prednisolone, or the equivalent, in initial doses of
Table 4. Treatments prescribed during the follow-up of patients with juvenile systemic lupus erythematosus

\begin{tabular}{lcc}
\hline & \multicolumn{2}{c}{ Patients with JSLE $(\mathrm{n}=30)$} \\
\cline { 2 - 3 } Treatments & $\mathrm{n}$ & $\%$ \\
\hline NSAID & 17 & 57 \\
Hydroxychloroquine & 18 & 60 \\
Oral corticosteroids & 27 & 90 \\
Pulse methylprednisolone & 16 & 53 \\
Cyclophosphamide & 11 & 37 \\
Azathioprine & 5 & 17 \\
Mycophenolate mofetil & 1 & 3 \\
Methotrexate & 2 & 7 \\
Cyclosporine & 4 & 13 \\
Etanercept & 1 & 3 \\
Infliximab & 1 & 3 \\
Petoxyphilline & 1 & 3 \\
Plasma exchange & 2 & 7 \\
\hline JSLE: Juvenile systemic lupus & erythematosus; & NSAID: \\
anti-inflammatory drug. & & \\
\hline
\end{tabular}

$2 \mathrm{mg} / \mathrm{kg} /$ day (maximum $60 \mathrm{mg} /$ day). These were then reduced gradually to a dosage adequate to control the disease clinically. Sixteen patients used pulse methylprednisolone (pulse MP): 13 for renal disease and three for central nervous system involvement and severe systemic disease. Hydroxychloroquine in doses of $6 \mathrm{mg} / \mathrm{kg} /$ day was used in 18 patients. Fourteen patients received immunosuppressive drugs with five having it in the form of azathioprine $(2 \mathrm{mg} / \mathrm{kg} /$ day $)$. Of these five patients, three received it for renal disease and two for CNS involvement. Cyclophosphamide (CYC) $(2-2-5 \mathrm{mg} / \mathrm{kg} /$ day) was administered to 11 patients, and all had renal involvement with severe systemic disease. Plasmapheresis was used in only two patients, both of whom had nephritis and systemic disease.

As shown in Table 5, six class II patients were treated with oral steroids, and four patients received

\begin{tabular}{|c|c|c|c|c|c|c|}
\hline \multirow[t]{2}{*}{ Treatments } & \multirow{2}{*}{$\frac{\text { Class II }}{(\mathrm{n}=6)}$} & \multirow{2}{*}{$\frac{\text { Class III }}{(\mathrm{n}=1)}$} & \multirow{2}{*}{$\frac{\text { Class IV }}{(\mathrm{n}=4)}$} & \multirow{2}{*}{$\frac{\text { Class V }}{(n=6)}$} & \multicolumn{2}{|c|}{ Total } \\
\hline & & & & & $\mathrm{n} / \mathrm{n}^{*}$ & $\%$ \\
\hline NSAID & 4 & & 1 & 3 & $8 / 17$ & 47 \\
\hline Chloroquine & 3 & 1 & 1 & 3 & $8 / 17$ & 47 \\
\hline Oral steroid & 6 & 1 & 4 & 6 & $17 / 17$ & 100 \\
\hline Pulse methylprednisolone & 4 & 1 & 2 & 6 & $13 / 17$ & 76 \\
\hline Pulse cyclophosphamide & 2 & & 3 & 5 & $10 / 17$ & 58 \\
\hline Azathioprine & & 1 & 1 & 1 & $3 / 17$ & 17 \\
\hline Mycophenolate mofetil & & & & 1 & $1 / 17$ & 5 \\
\hline Methotrexate & 1 & & & & $1 / 17$ & 5 \\
\hline Cyclosporine & 1 & & & 1 & $2 / 17$ & 11 \\
\hline Plasma exchange & 1 & & & 1 & $2 / 17$ & 11 \\
\hline
\end{tabular}




\begin{tabular}{|c|c|c|}
\hline Complications & $\mathrm{n}$ & $\%$ \\
\hline Dialysis & 1 & 3.3 \\
\hline Growth retardation & 7 & 23 \\
\hline Severe infection & 4 & 13 \\
\hline Retinopathy associated with SLE & 5 & 16 \\
\hline Mortality & 4 & 10 \\
\hline
\end{tabular}

NSAIDs with or without chloroquine. Pulse MP was used in four patients. Three needed it for the control of nephrotic syndrome and one for the presence of elevated serum creatinine. Two patients were treated with Pulse MP plus CYC. Methotrexate, cyclosporine, and plasma exchange were added to the treatment of one patient because of neurologic involvement. A class III patient had normal serum creatinine at presentation. She was treated with NSAIDs with or without chloroquine, azathioprine oral steroids, and pulse MP. Of the class IV patients, three were treated with pulse MP plus CYC while one patient was treated with oral steroids plus CYC. In the class V patients, four had elevated serum creatinine at presentation. All class V patients used pulse MP and oral steroids. Five of the class V patients used pulse MP plus CYC, and three were treated with NSAIDs with or without chloroquine. Plasma exchange, cyclosporine, and mycophenolate mofetil were used in only one patient without response.

Aseptic necrosis of the femoral head developed in one patient, visual field defect resulting from hydroxychloroquine treatment developed in two, cataracts in five, nephrolithiasis resulting from corticosteroid therapies in one, and controllable pneumonia in four patients. Other complications are summarized in Table 6.

The mean duration of response to treatment was 30 days (13-300 days). During the follow-up, four patients died (13\%), three of renal failure and one from severe sepsis. At their last visits, two patients were in remission without treatment, and 22 patients were in remission with treatment. Two patients were lost to follow-up.

\section{DISCUSSION}

This is the first report reviewing all clinical, laboratory, and pathological features of Turkish children with SLE. The mean age at diagnosis was 12.3 \pm 3.2 years. The disease was diagnosed before the age of 10 in $20 \%$ of the patients, and before the age of three in one patient who had poliarthritis, fever, pleural effusion, anemia, direct Coombs, ANA, antidsDNA, anti-RNP, anti-histone, and anti-nucleosome positivity on admission. In addition, discoid lupus and class II lupus nephritis were diagnosed during the follow-up.

The age at which our patients were diagnosed is similar to other studies involving children with SLE from western countries. ${ }^{[9,11,13,15]}$ Asia, and the Middle East. ${ }^{[10,12,14,17,18]}$ Previous studies found that the majority of children with SLE were over 10 years of age. ${ }^{[12,14,19,20]}$ The onset of SLE is rare before the age of five. ${ }^{[21]}$ Font et al. ${ }^{[9]}$ reported that one out of 34 patients presented clinical manifestations of SLE at the age of five, but none of their patients presented these manifestations before this age.

The female-to-male ratio in our study was 9:1. All childhood SLE studies. ${ }^{[9-14,15,19]}$ have described high female-to-male ratios (3-18:1) closer to the ratios reported in adult SLE.

A review of the literature reveals wide variations among different studies regarding the prevalence of childhood SLE manifestations. These variations may be related to differences in the genetic make-up of the patients since they come from various ethnic groups. It could also be from referral bias which occurred due to some studies being submitted from nephrology units and others from rheumatology units.

Most JSLE patients have musculoskeletal involvement, mainly arthritis, arthralgia, or tenosynovitis. Although myalgia is seen in $20-30 \%$ of patients, true myositis is seen much less frequently. ${ }^{[22]}$ The frequency of musculoskeletal involvement in our study is similar to other studies of Indian, ${ }^{[10,18]}$ Arabic, ${ }^{[12,23,24]}$ British, ${ }^{[11]}$ and American ${ }^{[13]}$ children. However, some other studies have reported lower percentages of musculoskeletal involvement than we did. ${ }^{[9,19,14]}$ Cutaneous disease may include a malar rash, photosensitivity skin rash, vasculitic skin lesions with nodules or ulceration, palmar/plantar erythema, Raynaud's phenomenon, or, less frequently, discoid lupus. ${ }^{[22]}$ Mucocutaneous involvement has been reported in $57-86 \%$ of patients at the time of JSLE diagnosis and in up to $85 \%$ of patients during the course of the disease. ${ }^{[9-14]}$ Mucocutaneous involvement was found in almost $70 \%$ of our patients at disease onset.

The characteristic neurologic manifestations of JSLE are seizures and psychosis, but a host of 


\begin{tabular}{|c|c|c|c|c|c|c|c|c|}
\hline & $\begin{array}{l}\text { ahabri et al. }{ }^{[12]} \\
\qquad(\mathrm{n}=60) \\
\text { Saudi Arabia })\end{array}$ & $\begin{array}{l}\text { Iqbal et al. }{ }^{[13]} \\
\qquad \begin{array}{c}(\mathrm{n}=39) \\
\text { (USA) }\end{array}\end{array}$ & $\begin{array}{l}\text { Bakr }^{[14]} \\
(\mathrm{n}=52) \\
\text { (Egypt) }\end{array}$ & $\begin{array}{l}\text { Caerio et al. }{ }^{[11]} \\
\qquad \begin{array}{c}(\mathrm{n}=42) \\
(\mathrm{UK})\end{array}\end{array}$ & $\begin{array}{c}\text { Agarwal et al. }{ }^{[18]} \\
(\mathrm{n}=70) \\
\text { (India) }\end{array}$ & $\begin{array}{c}\text { Chandrasekaran } \\
\text { et al. }{ }^{[10]} \\
(\mathrm{n}=59) \\
\text { (India) }\end{array}$ & $\begin{array}{l}\text { Font et al. }{ }^{[9]} \\
\qquad \begin{array}{l}(\mathrm{n}=34) \\
(\text { Spain })\end{array}\end{array}$ & $\begin{array}{c}\text { Present } \\
\text { study } \\
(\mathrm{n}=30) \\
\text { (Turkey) }\end{array}$ \\
\hline Musculoskeletal & 92 & 74 & 65 & 100 & 65 & 86 & 65 & 87 \\
\hline Mucocutaneous & 81 & 72 & 86 & 76 & 57 & 69 & 73 & 70 \\
\hline Renal & 65 & 28 & 80 & 47 & 54 & 49 & 20 & 56 \\
\hline Hematologic & 67 & 72 & 51 & 52 & 77 & 50 & 20 & 70 \\
\hline Central nervous system & em 30 & 28 & 8 & 26 & 21 & 27 & 26 & 23 \\
\hline Cardiac & 38 & 0 & 8 & 23 & 3 & 10 & 12 & 23 \\
\hline Pulmonary & 16 & 0 & 9 & 30 & 3 & 22 & 0 & 27 \\
\hline
\end{tabular}

additional signs and symptoms may occur. Headache and depression are the most common neuropsychiatric manifestations. ${ }^{[25]}$ Neuropsychiatric SLE occurs in $20-70 \%$ of JSLE. ${ }^{[22]} \mathrm{Bakr}^{[14]}$ reported a low frequency of neuropsychiatric abnormalities in children with SLE. However, our study, similar to reports coming from Saudi Arabia ${ }^{[12]}$ and western countries, ${ }^{[9,19,20]}$ pointed to a higher frequency of CNS abnormalities.

Anemia, thrombocytopenia, and leukopenia are seen in $50-75 \%$ of JSLE. The most common form of anemia is normochromic normocytic anemia which, when persistent, usually becomes microcytic and hypochromic anemia. ${ }^{[22]}$ The frequency of hematologic abnormalities in our study was similar to the Egyptian, ${ }^{[14]}$ Saudi Arabian, ${ }^{[12]}$ American, ${ }^{[13]}$ and Indian ${ }^{[18]}$ studies. However, a study from Spain reported a lower percentage of hematologic abnormalities. ${ }^{[9]}$

In our study, the most common form of cardiac involvement was pericarditis with pericardial effusion. Cardiovascular manifestations were noted in 23\% of our patients. Our results were similar to a study reported from the United Kingdom (UK), ${ }^{[1]}$ but our figures were higher than those reported in studies in children from India and Egypt. ${ }^{[10,14,18]}$ Pulmonary involvement has become increasingly recognized as a manifestation of SLE. Although our patients who experienced pulmonary disease did not suffer from complications, pulmonary lupus sometimes carries a serious prognosis. ${ }^{[26]}$ This problem was more frequent in our patients compared with Saudi Arabian, Egyptian, Spanish, and Indian children, ${ }^{[9,12,14,18]}$ but similar to what was seen in children in the UK. ${ }^{[1]}$

Clinically significant renal involvement in systemic lupus erythematosus is more common in children than in adults. ${ }^{[6,27,28]}$ Almost $56 \%$ of our patients presented renal involvement, which was similar to $65 \%$ of Saudi Saudi Arabian $^{[12]}$ and $54 \%$ of Indian ${ }^{[18]}$ SLE children. Lower frequencies of renal involvement in children with JSLE were reported in western countries. ${ }^{[9,11,13]}$ In our study, a renal biopsy was performed in all patients with clinical evidence of LN. Overall, six out of 17 (35\%) had class II, one out of 17 (5\%) had class III, four out of $17(23 \%)$ had class IV, and six out of 17 (35\%) had class V LN. The clinical manifestations of our patients with LN were similar to those seen in studies of children of the western countries. ${ }^{[9,11,13,20]}$ In this study, LN was evident at the time of diagnosis in all patients except four, who proceeded to develop $\mathrm{LN}$ within a year.

Bogdanović et al. ${ }^{[20]}$ reported that renal manifestations were present in $67 \%$ of patients at the time of SLE diagnosis. In $90 \%$ of SLE patients, LN appeared within two years of the onset of the disease. An earlier Turkish study of children with $\mathrm{LN}^{[29]}$ reported class IV (64\%) of LN as the most frequent histopathological pattern. Bakr ${ }^{[14]}$ stated that the biopsy distribution of the pathological classes of LN in Egypt was as follows: class I $4.9 \%$, class II $22 \%$, class III $36.7 \%$, and class IV 36.7\%. Upon examining biopsies of their patients, Agarwal et al. ${ }^{[18]}$ demonstrated that class II (44\%) and class IV (44\%) were the most common WHO classes. Similar to previous reports ${ }^{[10,14]}$ class II LN was the most common lesion in our study. However, western studies reported a higher percentage of class III and IV LN than did our study. ${ }^{[20,29,30]}$ The high proportion of patients with class V LN (35\%) and low proportion of class III LN (5\%) in our study in contrast to the $2-5 \%$ and $15-25 \%$ in other series respectively is not explainable. In the past, renal disease was the major cause of mortality in patients with JSLE, but with earlier diagnosis and newer methods of treatment, the outlook for patients with lupus nephritis has vastly improved. Table 7 summarizes our clinical findings compared with other studies.

Our patients showed good response to the different therapeutic modalities that were used in different combinations according to disease presentation and organ involvement. Treatment options have 
been studied in several centers with varied success. High-dose and long-term steroids, CYC, and other immunomodulators used in the treatment of SLE carry the risk of growth retardation along with severe infectious complications and drugs side effects, such as cataracts, defect of visual field, and avascular necrosis of the femoral head. In this study, steroids in combination with intermittent intravenous pulse and CYC were used in 10 children with lupus nephritis. Plasma exchange, cyclosporine, and mycophenolate mofetil were used in only one patient without response.

In the last decade, the prognosis for pediatric SLE has improved dramatically. ${ }^{[30]}$ It is known that renal disease and its treatment remain the main causes of morbidity and mortality. The prognosis in our series reflects the improved care for children with JSLE and longer life expectancy for these patients. Three patients, one was class II LN and the others were class V LN, died because of renal failure. One patient also died because of severe sepsis. Eighty seven percent of our patients are alive. Two patients were in remission without treatment, and 22 patients were in remission with treatment.

We conclude that the presentation and clinical course of SLE in our series of 30 children depends on organ involvement. Renal involvement and sepsis are the most important mortality causes in our pediatric patient group. Early diagnosis, better treatment protocols, and aggressive management of infections all have contributed to the improved outcome of this severe disease. The different rates of organ involvement in different countries may be related to differences in the genetic make-up of the patients who come from various ethnic groups. Referral bias could also provide another reason for the discrepancy as some studies were submitted from nephrology units and others from rheumatology units.

\section{Declaration of conflicting interests}

The authors declared no conflicts of interest with respect to the authorship and/or publication of this article.

\section{Funding}

The authors received no financial support for the research and/or authorship of this article.

\section{REFERENCES}

1. Vilá LM, Alarcón GS, McGwin G Jr, Friedman AW, Baethge BA, Bastian HM, et al. Early clinical manifestations, disease activity and damage of systemic lupus erythematosus among two distinct US Hispanic subpopulations. Rheumatology (Oxford) 2004;43:358-63.
2. Lehman TJ, McCurdy DK, Bernstein BH, King KK, Hanson V. Systemic lupus erythematosus in the first decade of life. Pediatrics 1989;83:235-9.

3. Platt JL, Burke BA, Fish AJ, Kim Y, Michael AF. Systemic lupus erythematosus in the first two decades of life. Am J Kidney Dis 1982;2:212-22.

4. Fessel WJ. Epidemiology of systemic lupus erythematosus. Rheum Dis Clin North Am 1988;14:15-23.

5. Yeh TT, Yang YH, Lin YT, Lu CS, Chiang BL. Cardiopulmonary involvement in pediatric systemic lupus erythematosus: a twenty-year retrospective analysis. J Microbiol Immunol Infect 2007;40:525-31.

6. Gloor JM. Lupus nephritis in children. Lupus 1998;7:639-43.

7. Wallace DJ. The musculoskeletal system. In: Wallace DJ, Hahn BH, editors. Dubois' lupus erythematosus. 6th ed. Philadelphia: Lippincott Williams \& Wilkins; 2002. p. 629-44.

8. Lang BA, Silverman ED. A clinical overview of systemic lupus erythematosus in childhood. Pediatr Rev 1993;14:194-201.

9. Font J, Cervera R, Espinosa G, Pallarés L, RamosCasals M, Jiménez $S$, et al. Systemic lupus erythematosus (SLE) in childhood: analysis of clinical and immunological findings in 34 patients and comparison with SLE characteristics in adults. Ann Rheum Dis 1998;57:456-9.

10. Chandrasekaran AN, Rajendran CP, Ramakrishnan S, Madhavan R, Parthiban M. Childhood systemic lupus erythematosus in south India. Indian J Pediatr 1994;61:223-9.

11. Caeiro F, Michielson FM, Bernstein R, Hughes GR, Ansell BM. Systemic lupus erythematosus in childhood. Ann Rheum Dis 1981;40:325-31.

12. Bahabri S, Sabban EA, Al Rashed A, Al-Mayouf S, Al Mazyed A, Abdulrazik A, et al. Juvenile systemic lupus erythematosus in 60 Saudi children. Ann Saudi Med 1997;17:612-5.

13. Iqbal S, Sher MR, Good RA, Cawkwell GD. Diversity in presenting manifestations of systemic lupus erythematosus in children. J Pediatr 1999;135:500-5.

14. Bakr A. Epidemiology treatment and outcome of childhood systemic lupus erythematosus in Egypt. Pediatr Nephrol 2005;20:1081-6.

15. Buoncompagni A, Barbano GC, Pistoia V, Fasce L, Micalizzi C, Gusmano R, et al. Childhood systemic lupus erythematosus: a review of 30 cases. Clin Exp Rheumatol 1991;9:425-30.

16. Churg J, Soi LH, editors. Renal disease: classification and atlas of glomerular diseases. New York: Igaku-Shoin Medical Pub; 1985.

17. Yalaoui S, Gorgi Y, Meddeb S, Makni S, Lakhoua R, Debbabi A, et al. Lupus in children in Tunisia. Rev Med Interne 1993;14:765-71. [Abstract]

18. Agarwal I, Kumar TS, Ranjini K, Kirubakaran C, Danda D. Clinical features and outcome of systemic lupus erythematosus. Indian Pediatr 2009;46:711-5. 
19. Tucker LB, Menon S, Schaller JG, Isenberg DA. Adultand childhood-onset systemic lupus erythematosus: a comparison of onset, clinical features, serology, and outcome. Br J Rheumatol 1995;34:866-72.

20. Bogdanović R, Nikolić V, Pasić S, Dimitrijević J, Lipkovska-Marković J, Erić-Marinković J, et al. Lupus nephritis in childhood: a review of 53 patients followed at a single center. Pediatr Nephrol 2004;19:36-44.

21. Dubois EL, Tuffanelli DL. Clinical manifestations of systemic lupus erythematosus. Computer analysis of 520 cases. JAMA 1964;190:104-11.

22. Benseler SM, Silverman ED. Systemic lupus erythematosus. Pediatr Clin North Am 2005;52:443-67.

23. Habib GS, Saliba WR. Systemic lupus erythematosus among Arabs. Isr Med Assoc J 2002;4:690-3.

24. Alsaeid K, Kamal H, Haider MZ, Al-Enezi HM, Malaviya AN. Systemic lupus erythematosus in Kuwaiti children: organ system involvement and serological findings. Lupus 2004;13:613-7.

25. Woo P, Laxer RM, Sherry DD. Systemic lupus erythematosus. In: Woo P, Laxer RM, Sherry DD, editors. Pediartic rheumatology in clinical practice. 1st ed. London: Springer-Verlag; 2007. p. 47-65.

26. Pines A, Kaplinsky N, Olchovsky D, Rozenman J, Frankl O. Pleuro-pulmonary manifestations of systemic lupus erythematosus: clinical features of its subgroups. Prognostic and therapeutic implications. Chest 1985;88:129-35.

27. Egner W. The use of laboratory tests in the diagnosis of SLE. J Clin Pathol 2000;53:424-32.

28. Wallace DJ, Hahn BH, Klippel JH. Clinical and laboratory features of lupus nephritis. In: Wallace DJ, Hahn BH, editors. Dubois' lupus erythematosus. 6th ed. Philadelphia: Lippincott Williams \& Wilkins; 2002. p. 1077-91.

29. Emre S, Bilge I, Sirin A, Kilicaslan I, Nayir A, Oktem F, et al. Lupus nephritis in children: prognostic significance of clinicopathological findings. Nephron 2001;87:118-26.

30. Baqi N, Moazami S, Singh A, Ahmad H, Balachandra S, Tejani A. Lupus nephritis in children: a longitudinal study of prognostic factors and therapy. J Am Soc Nephrol 1996;7:924-9. 